\title{
Why do we need to revisit the Cold War?
}

\author{
Wei Li ${ }^{1}[$
}

Received: 18 June 2020 / Accepted: 14 July 2020 / Published online: 28 July 2020

(C) The Institute of International and Strategic Studies (IISS), Peking University 2020

\begin{abstract}
Since the beginning of 2018, China and the US have engaged in increasingly fierce strategic competition in the economic and security spheres. The competition has extended to the new field of values since the outbreak of the COVID-19 pandemic in 2020. The escalating strategic competition will presumably evolve into a new Cold War between the two powers. The realization of a new Cold War will undoubtedly take a toll on not only the domestic development of the two countries, but also on the entire international society. Thus, it is of special significance to reexamine the origins and the tragic consequences of the Cold War between the US and the Soviet Union. In view of the reams of narratives on the history of the Cold War, this paper focuses on how reexamining the Cold War can promote better understanding and management of today's China-US relations.
\end{abstract}

Keywords Strategic competition · New cold war $\cdot$ China-US relations

\section{Introduction}

Although history might not simply repeat itself, this does not mean that historical analogies are meaningless. On the contrary, when a social scientist cannot understand the complicated and tumultuous world, it may be wise to calmly study and seek practical answers from history.

Since Trump came to power, and especially since the end of 2017, China-US relations have witnessed historic changes, including the beginning of the largest tariff war in the history of international economic relations and the onset of an unprecedented technological war against China by the US. A financial war seems to be in the offing amid increasing financial frictions between the two giants in 2020. Furthermore, there has been a formidable contest between the two powers on security and political issues related to Taiwan, Hong Kong, and the South China Sea. The

Wei Li

liwei09@ruc.edu.cn

1 School of International Studies, Renmin University of China, No. 59 Zhongguancun Street, Haidian District, Beijing, China 
release of the United States Strategic Approach to the People's Republic of China on May 20, 2020 marks, to some extent, the formation of the US's competitive strategy against China (The White House 2020).

The practice of China-US relations over the past 2 years has triggered several important academic and policy propositions: Will the comprehensive and accelerating strategic competition between China and the US evolve into a new Cold War? What are the consequences for world politics? How can a tragic China-US cold war be kept at bay? ${ }^{1}$ For the keys to these questions, we need to review the history of the Cold War between the US and the Soviet Union and learn modestly from experts on the Cold War.

\section{Rethinking these Cold War and its origin}

The concept of the "Cold War", which originated shortly after the end of the Second World War in 1946, emerged as a public political term in 1947 and has been widely used ever since. Despite being a specific term used to describe 4 decades of confrontation between the US and the Soviet Union, the term did not end with the end of the rivalry between the two, but instead is often used to describe other similar international phenomena due to its rich international political meaning and reflection of new international relations in the nuclear era.

As a concept opposite to a "hot war", a Cold War does not mean complete peace. A Cold War includes three essential features: first, there must be two well-matched power poles in the international system; it is difficult for unbalanced power poles or more than two power poles to give rise to a Cold War. Second, the two major power poles must mainly be competitors, not partners. Specifically, the competitive relationship must be reflected in diplomatic confrontation through alliances, mutual military deterrence and arms races, economic closure and isolation, and ideological attacks. Third, there must not be direct military conflict between the two polar powers. A common form of conflict in a Cold War is proxy war, which is the main form of competition between two polar powers. These three basic features, with the first describing power structure and the other two describing the state of the polar relationship, constituted the basic characteristics of the international system amid the US-Soviet confrontation.

The long-lasting Cold War between the US and the Soviet Union profoundly shaped global political, economic, and ideological patterns after World War II. The two countries were important anti-fascist allies in World War II, but they quickly slipped into the abyss of the Cold War just after the end of the war. This rapid and dramatic change is thought provoking. There were several reasons for the onset of the Cold War.

\footnotetext{
1 The "New Cold War" between China and the United States is a new topic at present. Important people from both sides have expressed relevant views. See Zhao (2019), Zheng (2018), He (2018), Lind (2018), Westad (2019) and Edel and Brands (2019).
} 
First, there was an upward spiral in US-Soviet strategic distrust when both countries had strong destructive military forces. The strategic distrust was a kind of political sentiment that was prone to arise after their common enemy disappeared. This tendency conforms to the general law of political science, because great fear triggered by security pressure is apt to induce sensitivity and suspicion in human nature. The preservation of the super armament power of the two nations brought new fear after the defeat of the US' and the Soviet Union's mutual enemy, Germany. Truman, the new US president, and Stalin, the aging leader of the Soviet Union, lost the confidence and patience to continue to communicate with each other. The two top leaders never met again after the Potsdam Conference. The physical separation of the decision makers from both sides contributed to the deterioration of mutual distrust.

Strategic distrust easily led to strategic miscalculation on both sides and then generated aggressive and risky strategic behavior, as both sides were unclear about each other's strategic intentions. Take the Korean War as an example. Many countries, including China, suffered major miscalculations. The Soviet Union and North Korea launched the war against the South Korea recklessly, because they misjudged a speech made by Dean Acheson, the US Secretary of State, in the early 1950s in which he excluded South Korea from the US's Pacific "defensive perimeter" (Gaddis 2011, 93). The US' misjudgment of China's resolve to send troops into North Korea led it to indulge in the commander of US Army forces in the Far East Gen. Douglas MacArthur's reckless crossing of the 38th Parallel into the north. At that time, China's top leaders also misjudged the strength and determination of the US military, leading Chinese troops to boldly cross the 38th parallel to the south. This is part of the reason why the Korean War continued, lasting for 3 years. The repeated strategic miscalculations made by China, the US, and the Soviet Union during the Korean War were disastrous. The Korean War was the most ruthless fight between the two camps led, respectively, by US and Soviet Union during the Cold War, which intensified the sharpness of the Cold War confrontation.

Second, the ideological attacks of the two sides exacerbated US-Soviet distrust. In addition to power confrontation, another important part of the Cold War was the ideological rivalry between the two power poles. The Cold War started largely with ideological attacks, with each side treating the other as an enemy. On February 9, 1946, Stalin placed special emphasis on Lenin's theory of capitalism and the inevitability of war at the Supreme Soviet conference, which caused great concern in the Western world. A few days later, George Kennan sent back the renowned " $\mathrm{X}$ Report" from Moscow, highlighting the ideological threat from the Soviet Union. Soon after, McCarthyism rose in the US. Fierce ideological conflict worsened the confrontation between the two power poles. In sum, the ideological conflict between capitalism and communism constituted an important part of the Cold War.

Third, strategic distrust and ideological attacks, which furthered the adoption of closed and exclusive economic policies on both sides, crippled opportunities for the US and the Soviet Union to pursue win-win interests. In 1944, Molotov, the Minister of Foreign Affairs of the Soviet Union, participated in the US-led Bretton Woods Conference, where he expressed his desire to cooperate with the US in the post-war reconstruction of the world economic order. However, after the war, the Soviet Union took an increasingly negative attitude toward participating in the 
American reconstruction plan and refused to join in the Marshall Plan, the International Monetary Fund (IMF), and the World Bank. Instead, it set up the Council for Mutual Economic Assistance, as Harry Dexter White, the "Father of the IMF" and an important designer of the Bretton Woods System, was exposed as a suspected Soviet spy. In addition, the US took further economic action by establishing the Coordinating Committee for Multilateral Export Controls (COCOM), which aimed at sanctions against communist countries. With the beginning of an economic cold war between the two sides, two parallel markets formed in the two camps, and the international economic system was artificially bisected. As an important part of the US-Soviet Cold War, the economic Cold War directly reduced social contact between the two sides, preventing the sharp political collision between the two sides from being offset.

Fourth, the two opposing power poles sought to build two powerful political groups for strategic confrontation through large-scale alliances to win the "struggle" in security, economics, and ideology. Although the US and the Soviet Union were the initiators and main competitors of the Cold War, the Cold War was not limited to only the two powers, but instead involved many countries. In view of this, the Cold War was not "individual combat", but rather involved battles among many countries whose foreign policies were shaped by the strategic patterns of the Cold War. In this sense, the Cold War resembled a huge machine that, once fully started, was difficult to stop due to the inertia caused by each bearing's rotation in line with an established direction and rhythm.

The evolution of the US-Soviet confrontation into a confrontation between two powerful camps further expanded the scale of the Cold War. The US took the lead in establishing the North Atlantic Treaty Organization (NATO), while the Soviet Union established the Warsaw Treaty Organization in response. The US-Soviet confrontation evolved into one between NATO and the Warsaw Treaty Organization. Under such huge structural pressure, alliance members consciously or unconsciously submitted to the needs of the struggle by taking sides in areas such as politics, economics, and ideology, and hardly had a third choice. Any member that sought to change this antagonistic group structure encountered great risks. Even if the two leading countries intended to ease their relations, there would be formidable consequences due to the interests of the allies behind them.

Fifth, third parties besides the US and the Soviet Union, especially allies within each group, often exacerbated the strategic confrontation between the two sides as triggers for the intensification of the confrontation. Although the two powers were absolutely the dominant players during the rise of the Cold War, third parties were still prone to breaking the fragile balance between the two.

For example, former British Prime Minister Churchill's "iron curtain” speech acted as a catalyst at the end of World War II. In addition, the unification war launched by Kim II Sung, which escalated into a full-scale fight between the two camps of the US and the Soviet Union on the Korean Peninsula and involved China, played a very important role in the realization of the Cold War in the Asia-Pacific region.

Moreover, many domestic conflicts in Vietnam, the Middle East, and other regions also triggered fierce competition between the two poles. As a result, the 
Cold War would get tightened just like a screw unless one side withdrew from the war after its own collapse.

In short, the Cold War formed gradually. Although it witnessed several periods of détente between the two sides over 40 years, the Cold War did not end with a win-win compromise, but with a tragically zero-sum comprehensive victory for one side and complete defeat for the other.

\section{Are China and the US heading for a new Cold War?}

US strategic circles held a 3-year policy debate on China beginning in 2015 (ChangLiao 2019). The US then introduced a number of hardline foreign policies towards China, marked by the introduction of the National Security Strategy of the US at the end of 2017 (The White House 2017). Accordingly, China responded strongly, and bilateral relations deteriorated rapidly. On May 20, 2020, the US issued the United States Strategic Approach to the People's Republic of China, officially announcing the end of its engagement strategy and designating the US strategy to China a competitive one (Brands 2018; Campbell and Ratner 2018).

Judging from the three criteria for a Cold War mentioned above, China-US relations may currently be approaching a "quasi-cold war", which is quite similar to the historical stage of the US and the Soviet Union in 1946-1947. There are still many uncertainties regarding whether China and the US will slide into a long-term Cold War in the future. This possibility depends on not only the national policy choices of policymakers, but also the perceptions of social elites and the public.

First, two power poles in the international system seem to be forming, although they are still not well balanced. This polar structure is most obviously embodied in the countries' economies. China's total economy accounts for more than $70 \%$ of that of the US and is more than twice the size of that of Japan, the third largest economy in the world. Combined, the economies of the US and China account for $40 \%$ of the world's total, with the US comprising about $25 \%$ and China about $15 \%$. If the EU is not regarded as a unified economy, a bipolar economic structure between China and the US is surfacing, and the gap between the two nations in economic aggregate terms may be further narrowed by the COVID-19 pandemic. In other words, the bipolar structure of the international economic system will become more evident in the next decade.

Moreover, China and the US rank as the world's top two countries in terms of military spending, comfortably ahead of Saudi Arabia, which ranks third. Of course, China, which is much weaker than the US in military strength, is generally far from being able to challenge the US militarily. There are also increasing apparent differences between the two sides in ideology and value system. China has been a unique civilization since ancient times. Since the Communist Party of China came into power, China has combined its traditional culture with Marxism in terms of ideology and value system. The differences in thoughts and values between China and the US were once suppressed and overshadowed by functional needs, as China's main approach since its reform and opening up was the massive absorption of modern market economy customs. But as it has made remarkable economic achievements, 
China has become more confident and has increasingly emphasized China's path and Chinese thinking. As a result, the value differences between the two powers have become more apparent. The pandemic outbreak has broadened the differences in values and development models between the two giants.

In short, China and the US occupy the two most important roles in today's international arena, while traditional players such as Europe, Japan, and Russia have seen their strategic position relatively decline. China-US relations now define the nature of the entire international system for the first time. The considerable imbalance between the two power poles, however, is the most obvious feature of the strength structure of the international system.

Second, the two power poles are confronted with increasingly obvious competition and even fierce confrontation in some areas, especially economics. Since economic frictions between China and the US broke out in a comprehensive fashion in March 2018, the two powers have launched extremely fierce conflicts in trade, industrial policy, intellectual property rights protection, market access, and other issues. The "trade war" of mutual tariff increases was officially realized in July 2018. At present, the two sides have built high tariff barriers, the economic frictions between the two sides are spreading to the financial sector, and the US' barriers to and stringent regulation of investments from China are escalating. If this round of the trade war fundamentally destroys the economic relationship between the two powers and compels gradual economic decoupling, it will mean that the embryo of an economic Cold War has taken shape (Li 2019).

In terms of diplomacy and military affairs, there has been fierce competition between China and the US, although the two sides have not yet launched a comprehensive diplomatic and military confrontation. The US began to shift its strategic focus to the Asia-Pacific region during the Obama era. During the Trump era, the concept of the Indo-Pacific region has served as a strong diplomatic signal for the US to balance against China's development of its Belt and Road Initiative (US Department of Defense 2019). A potential diplomatic confrontation has formed between the US-centered alliance and the strong partnership network that China is weaving, although the two groupings are not opposites. On the South China Sea issue, the two countries are in an initial situation of military conflict, engaging in verbal attacks and substantive military confrontation over relevant maritime navigation issues.

Ideologically, China has made it clear that it will not imitate America in politics or economics. The debate among American liberal elites on the reason for the failure of the US' engagement policy is quite similar to the one on who lost China in the 1940s (Tang 1963). Since March 2020, when the COVID-19 pandemic spread widely in the US, the two sides have fought a fierce public opinion war over the source of the COVID-19 virus and the best model for fighting the pandemic, aggravating the ideological divergences between them and antagonistic popular sentiments. Some scholars even believe that new McCarthyism is emerging in America (Schrecker 2018).

As the strategic competition between China and the US approaches that of a new Cold War, it is still hard to imagine that there will be direct military conflicts, especially large-scale wars, between the two giants. However, it will be difficult for 
the strategic relationship between the two countries to completely return to the one they shared during Cold War. The escalating strategic competition does not mean that the two countries will inevitably slide into a "tragedy of great power politics" (Mearsheimer 2001).

First, the past 40 years of development have brought deep economic interdependence between China and the US in many fields, such as trade, finance, and investment. Breaking the industrial division chains promoted by economic globalization will lead to extremely high costs, although some experts have noticed that China-US economic relations have already begun to decouple (Johnson and Gramer 2020).

China and the US are the most influential pair of trading and investment partners in the world, and China is one of the largest foreign holders of US Treasury bonds. Despite fierce trade conflicts between the two sides, the trade war has not fundamentally damaged their economic ties. They can hardly fully decouple from each other's economies due to their mature business networks and high economic complementarity. Even if possible, it would take quite a long time.

Second, China's adherence to the market economy path and opening to the outside world will greatly dilute the sharpness of the ideological struggle between it and the US despite emerging ideological confrontation, even though US accusations against China have risen to the level of political and economic systems and values.

For a long time, the main tone of China's domestic policies has been "connecting with international conventions". Both its reform of its market economy and the improvement of the quality of its university education were based on the mature experience and the standards and rules of the West. Although China has its own value and political system and is now aware of the disadvantages of Western values and systems, the Chinese have a measure of tolerance toward Western ideology after 4 decades of reform and opening up. Moreover, there has been a strong domestic opposition to the export of China's own ideology.

Third, China is unable or unwilling to engage in military expansion that challenges the core security interests of the US due to huge military gap between them. China's assessment of its own military strength is calm and prudent, although it is gradually gaining confidence in its own strength, especially its economic strength. Over the past few years, China has had paramilitary conflicts with Japan, the Philippines, Vietnam, India, and other countries, but no real military actions occurred, as all of them were suppressed.

The violent military competition between China and the US is in the South China Sea, which is China's offshore waters and involves many of China's key political and economic interests. China does not militarily compete with the US in locations distant from its own shores. Recent years have seen a considerable plummet in the growth of China's military expenditures. In a word, China's current military strategy hardly displays the same ambitions and capabilities as that of the post-war Soviet Union. China's highly defensive and inshore military and security strategy at present does not pose any meaningful challenge to the US.

Fourth, faced with the strong bilateral and multilateral alliance systems of the US, China still follows a policy of nonalignment and does not seek to conduct strategic confrontation with America through an antagonistic and exclusive alliance strategy. Instead, China is creating a favorable diplomatic environment for itself by weaving 
a more flexible and inclusive partnership network. This choice does not put pressure on other member states to take sides, and thus helps to avoid the rapid evolution of China-US strategic competition into a confrontation between the two closed groups. China has initiated the establishment of some international institutions and organizations in recent years, such as the Shanghai Cooperation Organization, the Asian Infrastructure Investment Bank (which China has always welcomed the US to join), the BRICs (Brazil, Russia, India, China, South Africa) mechanism, and the Lancang-Mekong Cooperation Mechanism, all of which are based on functional cooperation-unlike alliance systems, which have specific strategic targets.

In a word, the rising strategic competition between China and the US does take on some features of a new Cold War, but it has not yet reached the level of the US-Soviet Cold War. Whether China-US relations, at this important juncture, will evolve into a new Cold War depends on the understanding of the strategic elites of the two countries with regard to future world politics and the management of bilateral relations, although it is impossible to return to the engagement era of the past 40 years.

\section{The evil consequences of a new Cold War between China and the US}

The US-Soviet Cold War had very perilous consequences, putting the world on the brink of nuclear war in instances such as the Berlin Crisis and the Cuban Missile Crisis. In addition, it brought catastrophe to many Third World countries, such as the two countries on the Korean Peninsula. However, it was a complete tragedy for the Soviet Union, the loser of the war. If China and the US fight a "New Cold War", it will bring very serious consequences, not only endangering the normal development of the two countries, but also destroying the liberal international order that has been in place since the 1990s.

First, a "New Cold War" between China and the US may destroy the global industrial chain and reduce the efficiency of the world economy, as it may aggravate the economic nationalism of both sides and interfere with each other's openness to the outside world. The development of free trade, open finance, and global industrial division are all highly dependent on a peaceful and benign international environment. If the US imposes long-term increased import tariffs on China and China responds tit-for-tat in a spiraling trade war, the two countries' major markets will gradually decouple. With the development of a fierce technology war between the two countries, there will be a significant decoupling trend in high-tech industries. The economic interdependence between the two countries is the result of the logic of economic efficiency, whereas economic decoupling is a process dominated by the logic of security. If decoupling happens, the entire free international economic order will suffer enormous burdens.

Second, a new Cold War may worsen China's state-led economic system by forcing China to strengthen its whole national system and delay or even push back its market economy reforms. This violates the intentions of both China and the US. As the famous political economist Alexander Gerschenkron said a long time ago, 
late-developing countries are more likely to adopt economic development strategies through state intervention due to more severe external environments (Gerschenkron 1962). The development of the external environment of the new Cold War will encourage the Chinese government to play a greater role in guiding the market. Faced with the severe external pressure of a new Cold War, and in view of its less sound market system and weaker market power, China, unlike the US, can draw resources from society through market forces to engage in international strategic competition. Conversely, China may be compelled to strengthen its "visible hand" to control resources, including the extraction, distribution, and investment of resources. This would inevitably aggravate China's state-led economic system rather than promote market-oriented reform. This, in turn, would further widen the differences between the two countries' economic systems.

Third, a new Cold War is likely to intensify the arms race between China and the US and thus increase the financial burden on both. The US and Soviet Union had an extremely fierce arms race during the Cold War, although their confrontation did not trigger a hot war in the end. The collapse of the Soviet Union was largely due to the costly arms race, which it could not afford.

Since Trump came to power, the US has reversed its trend of cutting military spending during the Obama era and increased its military expenditure. But generally speaking, the US has many advantages in the arms race, as it has the dollar-a hegemonic currency through which the US can tax and borrow from the worldwhich provides support for its huge arms expenditures (Li 2015, 92-94). Apart from that, America's allies have helped share American military spending. China does not have these two advantages. Therefore, the grave financial and economic pressure that the arms race will bring to China will force the Chinese government to reduce its other expenditures, especially public expenditures, and will also weaken China's motivation and willingness to reduce taxes on a large scale. This will intensify social contradictions and curb economic growth. In sum, even though the US hold some advantages, the new wave of arms race is never the well-being of the two countries. China should particularly do its utmost to avoid slipping into the trap of an arms race with the US.

Fourth, a new Cold War may trigger more intense diplomatic competition, which will require a huge investment of resources. Since Obama came into power, the US has begun to implement a strategic contraction to reduce so-called "hegemonic costs" to revitalize its domestic economy. During the Trump era, on the whole, Trump has been willing to reduce the US' diplomatic investments and supply of international public goods by withdrawing from international organizations and institutions, although he has strengthened strategic investment in the Asia-Pacific region. China should not make diplomatic investments beyond its national strength due to its low per capita income and the pressure of targeted poverty alleviation. A new Cold War would undoubtedly force both China and the US to invest more in diplomatic resources, which would not contribute to their domestic development on the whole.

Fifth, a new Cold War may intensify the ideological closure and antagonism of both sides. Each country has its own values and beliefs. In a benign international system, people respect plural values and learn from each other ideologically, while 
in a vicious international system, aggression and radicalization in ideology are strengthened.

In short, the emergence of a new Cold War will bring many negative consequences to both China and the US, as well as to the international system as a whole. In particular, China, which is in a weak position, has a stronger wish to avert a new Cold War.

\section{How can China and the US avoid a New Cold War?}

Many pessimists believe that China-US relations may not be able to return to the engagement era that lasted 40 years. $^{2}$ However, the end of the US's engagement policy does not mean that China-US relations are doomed to misery. If the strategists and politicians of China and the US display superior strategic wisdom and historical vision and their elites and people show considerable mental maturity, the two sides will likely form a new stable balance after a fierce contest, so as to avoid a new Cold War in the new era.

First, China and the US should not engage in ideological competition, overemphasize ideological differences, or export their own ideology. Sharp ideological attacks between the US and the Soviet Union were an important part of the Cold War. The most classic scene in ideological debate might be the Kitchen Debate between Khrushchev and Nixon. The passion of ideology may impede decision makers and ordinary people from rational judgments and behaviors and enlarge or even solidify the differences between the two sides.

Both China and the US should show earnest respect for multiple civilizations and values and follow Deng Xiaoping's principle of "no dispute". Neither party should use sharp criticism of the model, system, and values of the other to enhance its own legitimacy, nor should either take the initiative to impose on any other country its own values and system. As global powers, both China and the US have their own successful experiences and internal shortcomings and should respect each other and refrain from ideological propaganda wars.

Furthermore, the power elites and intellectual elites of both countries should be responsible for curbing radical nationalist sentiment at home. Trump's "America First" stance has a high degree of nationalism and is apt to arouse xenophobic sentiments among ordinary Americans. China should also practice the principle of the "community of shared future for mankind" to avoid the fermentation of domestic nationalism and egoism. ${ }^{3}$

Second, neither party should limit normal economic and social exchanges that do not endanger national security or generalize the concept of national security, although China-US decoupling in some high-tech fields may be inevitable. In

\footnotetext{
2 After 2015, the US strategic community launched major debates on policies toward China, focusing on the "engagement strategy". In 2018, most scholars believed that this strategy failed.

3 The "community of shared future for mankind" is now the most common used official rhetoric by China, see Xi (2017).
} 
addition, neither party should punish the other by cutting off official contacts, which only serves to punish bilateral relations.

At the leadership level, leaders across different levels need to exercise more patience to communicate with those of the other side, especially at difficult times. In 2017, China and the US established four high-level dialogue mechanisms in strategy, economics, cultural exchange, and law enforcement. Subnational leaders who can solve practical problems lead the four dialogue mechanisms in China. The four mechanisms need to be maintained even if they fail to achieve effective results in the short term, because they can effectively ensure the exchange of views and information between China and the US on major issues. Moreover, the heads of China and the US have many opportunities for bilateral meetings on multilateral platforms every year. These meetings across various multilateral platforms should be maintained even if the heads cannot pay regular visits to each other. Such institutionalized meetings among leaders can at least settle some conflicts caused by misunderstanding, although they may not be able to completely solve some structural contradictions. In diplomatic relations, empty talk itself is also meaningful. Therefore, both sides should not readily or arbitrarily interrupt various forms of high-level dialogue mechanisms, but should instead intensify the institutionalization of such dialogues.

At the economic level, the two sides should appropriately consider some inexorable factors when they faithfully implement the first phase trade agreement reached in January 2020. Both sides should strive to build the credibility of their own strategy, as the extremely high cost of strategic deception between great powers may bring disastrous consequences. China should open wider to the outside world and increase the number of foreign stakeholders in the Chinese market by encouraging free trade and attracting foreign investment. A new Cold War between China and the US will be less likely to break out as long as China's market is more open and China is more deeply involved in the global division of labor. Even if it encounters obstacles in opening to the US, China should expand its opening to developed economies such as Europe and Japan and strengthen its trade and investment ties with them. This can exert pressure on the relevant domestic actors of the US and ensure the economic goodwill of its allies towards China.

At the social level, non-political activities, such as cultural exchanges, tourism, and education should be strengthened. The political and economic disputes between the two sides should not readily spread to social and cultural exchanges. One of the important differences between China-US relations and Sino-Soviet relations is the presence of extensive and diversified social exchanges. Over 40 years of development have brought a close and complex network of interpersonal relations between China and the US, which links academia, industry, and ordinary families. The political leaders of both sides should not readily bring their conflicting political ideas into the social realm or adopt any policies to prevent normal social exchanges.

Third, the two sides should not readily establish a united front against each other. Bilateral problems should be solved by only the two sides instead of involving outside parties. It is very dangerous for Trump to attempt to establish an Indo-Pacific alliance and strengthen the so-called "Five Eyes" alliance. This will force China to try to establish a counter-alliance in response. China should also take the "Belt and 
Road" Initiative as a means of pursuing economic cooperation instead of making it a multilateral political group.

China should not take the initiative to provoke a group struggle between itself and the US, as it is in a weak position on the whole. It is right for China to adhere to its non-alignment policy at present. Recent years have seen the development of China's initiative of international institutions, none of which should be designed to exclude or target the US. China should still seek to join many regimes led by the US and develop cooperative relations with its allies. In terms of national security, China should improve its relations with India, South Korea, Australia, and Southeast Asian countries to prevent them from aligning with the US too closely. Economically, China should strengthen its economic cooperation with Japan and European countries to reduce the likelihood of the Trump administration's establishment of a US-Europe-Japan economic alliance against China.

In summary, the intensity and scale of the strategic competition between China and the US cannot be put on par with that between the US and the Soviet Union during the Cold War, and the onset of a new Cold War will be made much less likely as long as the two sides do not build competing camps against each other.

\section{Epilogue}

Discussion about a new Cold War between China and the US is not pointless. SinoUS relations are widely believed to have entered a new stage, although we cannot judge with assurance the basic characteristics of this new stage. If China and the US slip into a new Cold War, it will bring the world significant political consequences. In particular, the arrival of a new external environment will have a profound impact on the development trajectory of China, which is in a weaker position. China's political, economic, and other communities should be alert to this new phenomenon and take prudent and wise measures to manage it.

Acknowledgements The author is indebted to Professor Fan Jishe for his encouragement and support for the writing of this article. The author is also grateful to Dr. Qi Hao, as the basic idea of this paper was read out for the first time in a discussion group organized by Dr. Qi.

\section{References}

Brands, Hal. 2018. The Chinese Century? The National Interest. https://nationalinterest.org/feature/thechinese-century-24557. Accessed 10 Apr 2020.

Campbell, Kurt M., and Ely Ratner. 2018. The China reckoning: How Beijing defied american expectations. Foreign Affairs 97 (2): 60-70.

Chang-Liao, Nien-Chung. 2019. From engagement to competition? The logic of the US China policy debate. Global Policy 10 (2): 250-257.

Edel, Charles, and Hal Brands. 2019. The real origins of the US-China Cold War. Foreign Policy. https ://foreignpolicy.com/2019/06/02/the-real-origins-of-the-u-s-china-cold-war-big-think-communism/. Accessed 10 Apr 2020.

Gaddis, John Lewis. 2011. The long peace: Inquiries into the History of the Cold War. trans. Yaling Pan. Shanghai: Shanghai People's Publishing House. 
Gerschenkron, Alexander. 1962. Economic backwardness in historical perspective. Cambridge: Belknap Press.

He, Yafei[何亚非]. 2018. Will China and the United States Launch a “New Cold War”? (中美会进入“ 怜战”吗?). China-US Focus. https://cn.chinausfocus.com/foreignpolicy/20180703/30201.html. Accessed 10 Apr 2020.

Johnson, Keith, and Robbie Gramer. 2020. The Great decoupling. Foreign Policy. https://foreignpolicy. com/2020/05/14/china-us-pandemic-economy-tensions-trump-coronavirus-covid-new-cold-wareconomics-the-great-decoupling/. Accessed 10 Apr 2020.

Li, Wei[李巍]. 2015. Balancing the US Dollar: Political Leadership and Currency Appreciation(制衡美 元:政治领导与货币崛起). Shanghai: Shanghai People's Publishing House.

Li, Wei. 2019. Towards economic decoupling? Mapping Chinese discourse on the China-US trade war. The Chinese Journal of International Politics 12 (4): 519-556.

Lind, Michael. 2018. America vs. China and Russia: Welcome to Cold War II. The National Interest. https://nationalinterest.org/feature/america-vs-russia-china-welcome-coldwar-ii-25382. Accessed 10 Apr 2020.

Mearsheimer, John J. 2001. The tragedy of great power politics. New York: W.W. Norton \& Company.

Schrecker, Ellen. 2018. Trumpism is the new McCarthyism. The Nation. https://www.thenation.com/artic le/archive/trumpism-is-the-new-mccarthyism/. Accessed 10 Apr 2020.

Tang, Tsou. 1963. America's failure in China, 1941-1950. Chicago: The University of Chicago Press.

The White House. 2017. National Security Strategy of the United States of America. https://www.white house.gov/wp-content/uploads/2017/12/NSS-Final-12-18-2017-0905.pdf. Accessed 10 Apr 2020.

The White House. 2020. United States Strategic Approach to the People's Republic of China. https:// www.whitehouse.gov/wp-content/uploads/2020/05/U.S.-Strategic-Approach-to-The-Peoples-Repub lic-of-China-Report-5.20.20.pdf. Accessed 10 Apr 2020.

U.S. Department of Defense. 2019. Indo-Pacific strategic report: preparedness, partnerships, and promoting a networked region. https://media.defense.gov/2019/Jul/01/2002152311/-1/-1/1/DEPAR TMENT-OF-DEFENSE-INDO-PACIFIC-STRATEGY-REPORT-2019.PDF. Accessed 10 Apr 2020 .

Westad, Odd Arne. 2019. The sources of Chinese conduct: Are Washington and Beijing fighting a new Cold War. Foreign Affairs 98 (5): 86-95.

Xi, Jinping[习近平]. 2017. Building a community with a Shared future for mankind(共同构建人类 命运共同体). Speech delivered at UN Geneva Center. People's Daily. https://cpc.people.com.cn/ n1/2017/0120/c64094-29037658.html. Accessed 10 Apr 2020.

Zhao, Minghao. 2019. Is a new Cold War Inevitable? Chinese perspectives on US-China strategic competition. The Chinese Journal of International Politics 12 (3): 371-394.

Zheng, Yongnian[郑永年]. 2018. The coming new Cold War Between China and the United States (即 将来临的中美新泠战). Zaobao. https://www.zaobao.com.sg/forum/expert/zheng-yong-nian/story 20180313-842282. Accessed 10 Apr 2020. 